\title{
THE FERMENTATION, ISOLATION AND CHARACTERIZATION OF A MACROMOLECULAR PEPTIDE ANTIBIOTIC: AN-3
}

\author{
Shigeyoshi Miyashiro, Takao Kida, Hiroshiro Shibai, \\ Tsuyoshi SHIIO and SHIGEzo UDAKA* \\ Central Research Laboratories, Ajinomoto Co., \\ Kawasaki, Kanagawa 210, Japan \\ *Faculty of Agriculture, Nagoya University, \\ Chikusa, Nagoya 464, Japan \\ (Received for publication April 15, 1983)
}

\begin{abstract}
A new macromolecular peptide antibiotic, named $\mathrm{AN}-3$, was isolated from the culture broth of Streptomyces albulus.

From 19 liters of culture broth containing AN-3 with 90 units/ml activity, a $400 \mathrm{mg}$ sample with a specific activity of 109 units/mg was obtained. Purified AN-3 gave a single band on polyacrylamide gel electrophoresis.

AN-3 was a basic polypeptide with a molecular weight of $12,000 \sim 12,500$ and an isoelectric point of pH 7.6. It showed a peak of absorption at $280 \mathrm{~nm}$ and seemed to have no nonprotein chromophoric component. It was soluble in water but insoluble in ethanol, butanol and acetone, and was stable at $\mathrm{pH} 4 \sim 9$ but unstable at $\mathrm{pH} 2$.

AN-3 had no antibacterial activity against Gram-positive and Gram-negative bacteria so far as tested. But, it showed a strong inhibitory effect on a macromolecule permeable mutant of Escherichia coli. It was not mutagenic. It appeared to inhibit synthesis of DNA and RNA without affecting DNA itself. It also inhibited the in vitro cell growth of L1210 and its $\mathrm{ED}_{50}$ was $5 \mu \mathrm{g} / \mathrm{ml}$. AN-3 had antitumor activity against Lewis lung carcinoma in mouse in vivo.
\end{abstract}

After developing a new assay system employing a macromolecule permeable strain and its DNA repair mutants, we searched for new peptide antibiotics with a DNA-interacting property ${ }^{1)}$. As a result, we found three different kinds of peptide antibiotics, $\mathrm{AN}-1, \mathrm{AN}-3$ and $\mathrm{AN}-7$, i.e. their modes of action were different from each other ${ }^{2)}$. Judging from the response of DNA repair mutants to the drug, AN-1 and AN-7 were antibiotics of the DNA-binding type and DNA-degrading type, respectively. AN-3 did not indicate any direct DNA-interacting property.

As reported previously ${ }^{3)}$, the optimal culture conditions for the production of AN-3 were investigated on a laboratory scale, aiming at its large scale production.

This paper describes bench-plant scale fermentation, the successive purification procedure, and some physicochemical and biological properties of AN-3. A comparison of AN-3 with already discovered peptide antibiotics is also made.

\section{Materials and Methods}

\section{Microorganisms}

Streptomyces albulus AAP-23 AJ9422 was employed in this study for the production of AN-3. This strain was newly isolated and identified in our laboratory.

Strain MP2, a macromolecule-permeable mutant of Escherichia coli W3876, and UR3, a uvrA and recA defective derivative of MP2, were used for the assay of antibiotic activity ${ }^{11}$. L7 was a valinesensitive derivative of MP2 and used for the mutagenicity test ${ }^{1}$. 
Media

The seed medium contained $1 \%$ glucose, $1 \%$ starch, $0.5 \%$ polypepton, $0.5 \%$ meat extract, $0.3 \%$ $\mathrm{NaCl}, 1 \mu \mathrm{g} / \mathrm{ml} \mathrm{FeSO}_{4} \cdot 7 \mathrm{H}_{2} \mathrm{O}, 1 \mu \mathrm{g} / \mathrm{ml} \mathrm{MnSO}_{4} \cdot 4 \mathrm{H}_{2} \mathrm{O}$ and $0.1 \% \mathrm{KH}_{2} \mathrm{PO}_{4}$. The fermentation medium was composed of $2 \%$ glucose, $0.5 \%$ Polypepton, $0.5 \%$ dried yeast, $0.5 \%$ meat extract, $0.5 \% \mathrm{NH}_{4} \mathrm{NO}_{3}, 0.5 \%$ $\mathrm{NaCl}, 20 \mu \mathrm{g} / \mathrm{ml} \mathrm{MnSO}{ }_{4} \cdot 4 \mathrm{H}_{2} \mathrm{O}$ and $0.2 \% \mathrm{CaCl}_{2} \cdot 2 \mathrm{H}_{2} \mathrm{O}$; the $\mathrm{pH}$ was adjusted to 7.0 with $\mathrm{NaOH}$.

The compositions of PM and M3 media, which were employed for the antibacterial assay, and M9V medium used for the mutagenicity test were given in our previous papers ${ }^{1,2)}$.

\section{Fermentation}

$\overline{S . ~ a l b u l u s ~ c e l l s ~ w e r e ~ g r o w n ~ i n ~ t h e ~ s e e d ~ m e d i u m ~ a t ~} 29^{\circ} \mathrm{C}$ for 24 hours and then transferred to the fermentation medium at an inoculum size of $10 \%$. The fermentation was carried out in a jar-fermentor with a working volume of 20 liters at $29^{\circ} \mathrm{C}$ for 2 days. The air flow rate was $1 / 2 \mathrm{v} / \mathrm{v} /$ minute and the agitation speed $350 \mathrm{rpm}$. The dissolved oxygen level was maintained above $0.01 \mathrm{~atm}$ under these oxygen supply conditions.

\section{Determination of Antibacterial Activity}

Antibacterial activity was measured using UR3, according to the disk assay method described previously ${ }^{1,2)}$. One unit of antibacterial activity was defined as the antibiotic concentration giving a $10 \mathrm{~mm}$ (diameter) inhibition zone. One mg of purified AN-3 showed activity equivalent to 109 units.

\section{Mutagenicity Test}

One $\mathrm{ml}$ of a cell suspension $\left(4 \times 10^{8}\right.$ cells $\left./ \mathrm{ml}\right)$ of $E$. coli $\mathrm{L} 7$ was treated with $1 \mathrm{ml}$ of various concentrations of $\mathrm{AN}-3$ at $37^{\circ} \mathrm{C}$ for 2 hours. After centrifugation, the cells were washed once with M3 medium, and resuspended in the same medium. An aliquot of the cell suspension was spread on an M9V plate and incubated at $37^{\circ} \mathrm{C}$ for 4 days. The number of valine resistant mutants appearing on the M9V plate was determined. The mutation frequency was estimated as the number of valine resistant colonies among the survivors.

\section{Antitumor Activity against L1210 In Vitro}

L1210 leukemia cells were cultured in the presence of various concentrations of AN-3 in EAGLE's minimum essential medium supplemented with $10 \%$ calf serum, $5 \mu \mathrm{g} / \mathrm{ml}$ cefazolin and $100 \mu \mathrm{g} / \mathrm{ml}$ streptomycin at an initial cell density of $6 \times 10^{2}$ cells $/ \mathrm{ml}$ at $37^{\circ} \mathrm{C}$ in an incubator with $7 \% \mathrm{CO}_{2}$. After 4 day's cultivation, the cell density was determined under a microscope and the $\mathrm{ED}_{50}$ value determined.

\section{Antitumor Activity In Vivo}

L1210 leukemia cells $\left(1 \times 10^{5}\right)$ were inoculated into BDF1 mice intraperitoneally. Twenty four hours after the inoculation, $3 \sim 50 \mathrm{mg} / \mathrm{kg}$ of AN-3 was injected intraperitoneally daily for 5 days. Antitumor activity was indicated by the increase in life span.

Lewis lung carcinoma cells $\left(1 \mathrm{~mm}^{3}\right)$ were transplanted subcutaneously into BDF1 mice. Twenty four hours after the transplantation, $3 \sim 50 \mathrm{mg} / \mathrm{kg}$ of AN-3 was injected intraperitoneally daily for $1 \sim$ 10 days. Antitumor activity was shown by the reduction in tumor size.

\section{Effect of AN-3 on Synthesis of DNA, RNA and Protein}

E. coli MP2 cells cultured in M3 medium were treated with AN-3 at different concentrations for various periods of time at $37^{\circ} \mathrm{C}$ with shaking. Cells were collected by centrifugation, washed with M3 medium, and then resuspended in the same medium. To $0.5 \mathrm{ml}$ of the cell suspension, $1 \mu \mathrm{Ci}$ of [methyl$\left.{ }^{3} \mathrm{H}\right]$ thymidine (specific activity, $\left.61.7 \mathrm{Ci} / \mathrm{mmol}\right),\left[5,6-{ }^{3} \mathrm{H}\right]$ uracil $(38.8 \mathrm{Ci} / \mathrm{mmol})$ or $\left[4,5-{ }^{3} \mathrm{H}\right]$ leucine $(65 \mathrm{Ci} /$ mmol) were added and the suspension was inoculated at $37^{\circ} \mathrm{C}$ on a shaker. Samples of $0.1 \mathrm{ml}$ were removed from the suspension at different times, transferred to $2 \mathrm{ml}$ of cold $5 \%$ trichloroacetic acid (TCA), and chilled in an ice bath. TCA insoluble materials were collected on a membrane filter and washed four times with $5 \%$ TCA followed by once with $1 \%$ TCA. The filters, after being dried for 30 minutes under a lamp, were soaked in toluene scintillation fluid, and their radioactivities were counted with a liquid scintillation spectrometer. Radioactivities incorporated into each macromolecule were plotted against time and the initial rate of incorporation was calculated. 
Analysis

Cell growth was expressed as packed mycelial volume (PMV) of $2 \mathrm{ml}$ culture.

Gel filtration on a column of Bio-Gel P-30 and SDS polyacrylamide gel electrophoresis were employed to determine the molecular weight of AN-3.

The isoelectric point of macromolecular peptide antibiotics was determined with a model SJ-1071 electrofocusing apparatus, Atto Co. Inc., equipped with Servalyt Precortes, $\mathrm{pH} 3 \sim 10$.

To determine the amino acid composition, protein samples were hydrolyzed in $6 \mathrm{~N} \mathrm{HCl}$ at $110^{\circ} \mathrm{C}$ for 24 hours and then applied to a Hitachi KLA-5 amino acid analyzer.

Chemicals

Neocarzinostatin and bleomycin were obtained from Yamanouchi Pharmaceutical Co., and Nippon Kayaku Company, respectively. Labeled compounds were obtained from New England Nuclear.

\section{Results}

\section{Fermentation}

The time course of AN-3 production is shown in Fig. 1. The antibiotic was produced at the late stationary phase of growth, amounting to 90 units $/ \mathrm{ml}$. The efficiency of AN-3 production in the jarfermentor was similar to that in a flask scale culture. ${ }^{3)}$

\section{Purification}

Mycelia were removed by centrifugation from 19 liters of culture broth with antibacterial activity of 90 units $/ \mathrm{ml}$. The $\mathrm{pH}$ of the supernatant was adjusted to 6.0 with $\mathrm{HCl}$. Solid ammonium sulfate was added to the supernatant to $80 \%$ saturation to precipitate the peptide antibiotic. After holding the solution at $4^{\circ} \mathrm{C}$ for 18 hours, the precipitate $(0.4 \mathrm{~kg}$ in wet) was harvested by centrifugation and dis-

Fig. 1. Time course of production of $\mathrm{AN}-3$ by $S$. albulus.

The fermentation was carried out in a 30-liter jarfermentor.

(•), Antibacterial activity; (○), growth; ( $\square$ ), glucose; $(\triangle), \mathrm{pH}$.

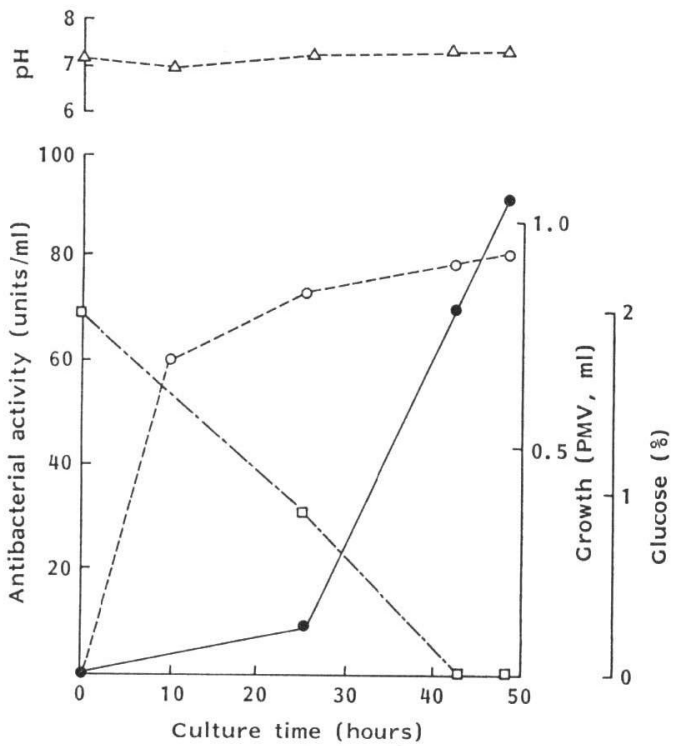

solved in 5 liters of $0.02 \mathrm{M}$ phosphate buffer containing $0.1 \mathrm{M} \mathrm{NaCl}(\mathrm{pH} 7.2)$. Then the antibiotic solution was dialyzed against running deionized water at room temperature for 48 hours. Fifteen

Fig. 2. Chromatography of $\mathrm{AN}-3$ on a column of CM-cellulose.

The active fraction that passed through a column of DEAE-cellulose was applied on a CM-32 column. The chromatography procedure was described in Results. (๑), Activity; (O), $\mathrm{OD}_{280}$.

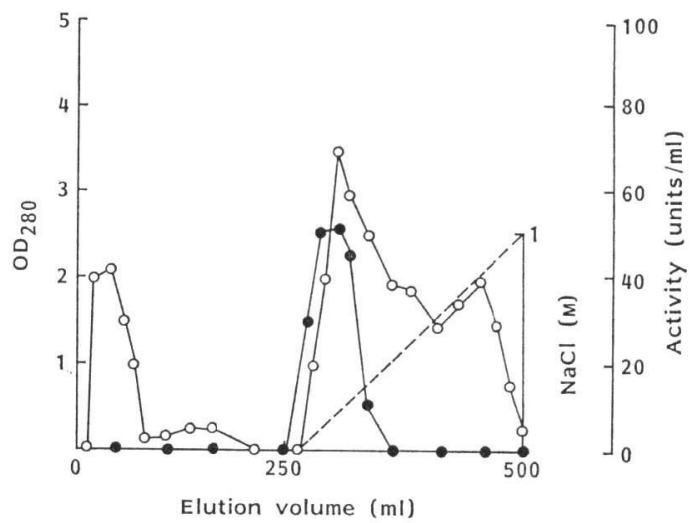


Fig. 3. SDS-polyacrylamide gel electrophoresis of AN-3.

Proteins were separated by electrophoresis on $20 \%$ acrylamide gel containing $1 \%$ SDS. (1), Marker proteins of known molecular weight; (2), crude AN-3 (proteins of culture supernatant precipitated by ammonium sulfate); (3), purified AN-3.

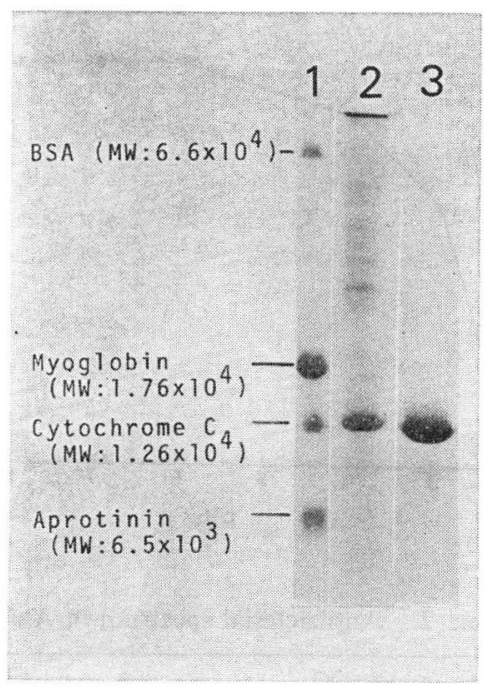

liters of acetone was added to the dialysate and $1.5 \mathrm{~g}$ of dry acetone precipitate was obtained. The precipitate was dissolved in $200 \mathrm{ml}$ of $0.02 \mathrm{M}$ phosphate buffer ( $\mathrm{pH}$ 7.2) and applied to a DEAE-cellulose (Whatman DE-52) $(1.6 \times 40 \mathrm{~cm})$. The eluant used was $0.02 \mathrm{M}$ phosphate buffer, $\mathrm{pH} 7.2$, and the active fraction passed through the column. About $200 \mathrm{ml}$ of the effluent that passed through was dialyzed against 10 liters of $0.002 \mathrm{M}$ acetate buffer $(\mathrm{pH} 5.0)$ at $5^{\circ} \mathrm{C}$ for 24 hours and then applied to a column of CM-cellulose (Whatman CM-32) $(1.6 \times 40 \mathrm{~cm})$. Elution was initially done with $0.02 \mathrm{M}$ acetate buffer ( $\mathrm{pH}$ 5.0), followed with the same buffer of increasing salt concentration. As shown in Fig. 2, AN-3 was eluted with $0.05 \mathrm{M} \mathrm{NaCl}$. Acetone was added to $74 \mathrm{ml}$ of the active fraction to the final concentration of $75 \%$, and the precipitate was dissolved in $10 \mathrm{ml}$ of water. This solution was subjected to gel filtration on a

column $(1.6 \times 40 \mathrm{~cm})$ of Bio-Gel P-30 and elution was done with water. After the active fraction was harvested, it was dialyzed against water at $5^{\circ} \mathrm{C}$ for 24 hours and then lyophilized. Antibiotic AN-3 thus purified weighed $400 \mathrm{mg}$ with 109 units/mg of activity.

The purified sample of AN-3 gave a single band on polyacrylamide gel electrophoresis (Fig. 3).

\section{Physicochemical Properties}

Some physicochemical properties of AN-3 were determined.

The isoelectric point of this antibiotic was approximately 7.6, as determined by electrofocusing.

It was soluble in water, but insoluble in organic solvents such as ethanol, butanol and acetone. It was obtained as a white powder and positive for the ninhydrin and biuret reactions, but negative for the anthrone and Blix reactions. These results indicate that $\mathrm{AN}-3$ is a peptide without sugar or aminosugar.

The molecular weight of AN-3 was 12,000, as measured with a Bio-Gel P-30 gel filtration system, and 12,500 as measured by polyacrylamide gel electrophoresis.

Fig. 4. Infrared spectrum of AN-3 (KBr).

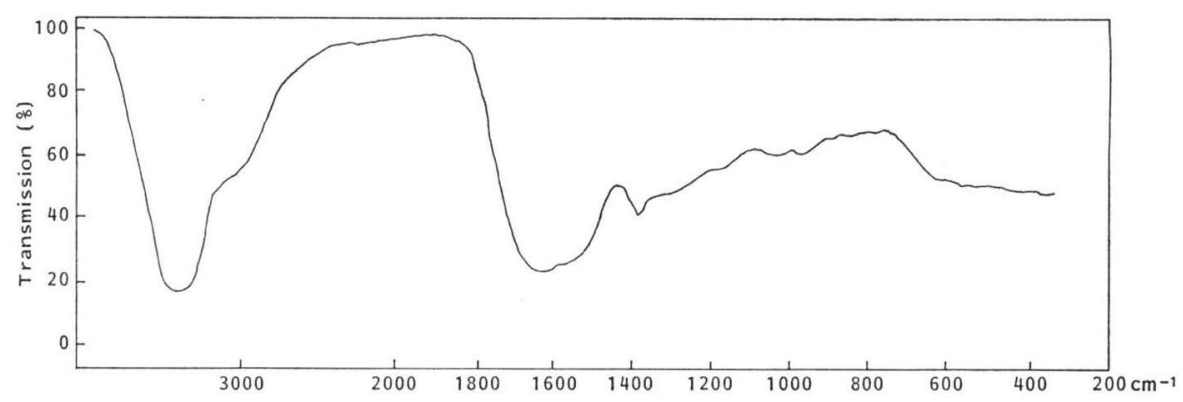


Fig. 5. Ultraviolet absorption spectrum of $\mathrm{AN}-3$.

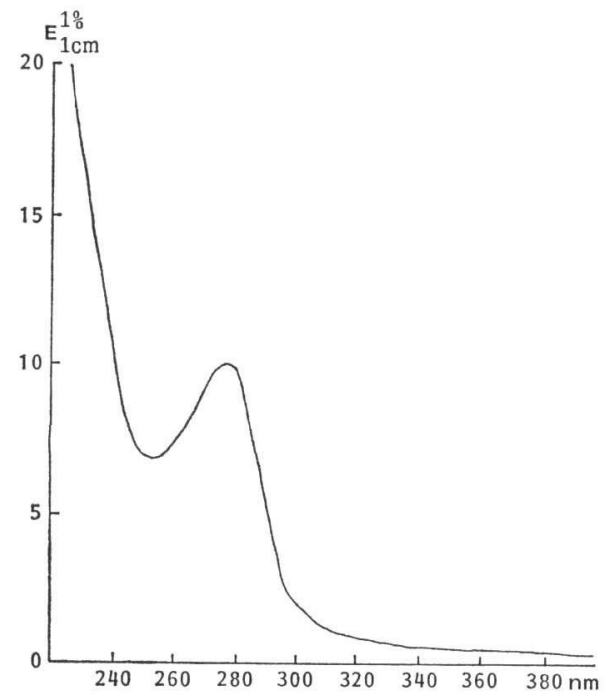

Table 1. Amino acid composition of AN-3.

\begin{tabular}{lc|cc}
\hline $\begin{array}{c}\text { Amino } \\
\text { acids }\end{array}$ & $\begin{array}{c}\text { Content } \\
(\%)\end{array}$ & $\begin{array}{c}\text { Amino } \\
\text { acids }\end{array}$ & $\begin{array}{c}\text { Content } \\
(\%)\end{array}$ \\
\hline Lys & 7.2 & Asp & 1.5 \\
Arg & 5.8 & Ser & 7.8 \\
Thr & 10.2 & Pro & 6.2 \\
Glu & 9.3 & Ala & 9.9 \\
Gly & 9.3 & Val & 7.1 \\
Met & 0.8 & Ile & 3.8 \\
Leu & 6.2 & Tyr & 5.7 \\
Phe & 3.3 & Cys & $-*$ \\
His & 3.0 & Trp & - \\
\hline
\end{tabular}

* Not determined.
Fig. 6. Effect of $\mathrm{pH}$ on the stability of $\mathrm{AN}-3$. AN-3 $(500 \mu \mathrm{g} / \mathrm{ml})$ was treated in $0.05 \mathrm{M}$ buffer of the indicated $\mathrm{pH}$ for 48 hours at $37^{\circ} \mathrm{C}$. The buffers used were mixtures of citric acid and $\mathrm{Na}_{2} \mathrm{HPO}_{4}$ for pH $2 \sim 5, \mathrm{KH}_{2} \mathrm{PO}_{4}$ and $\mathrm{Na}_{2} \mathrm{HPO}_{4}$ for pH 7, and Tris(hydroxymethyl)aminomethane and $\mathrm{HCl}$ and $\mathrm{HCl}$ for $\mathrm{pH} 8 \sim 9$.

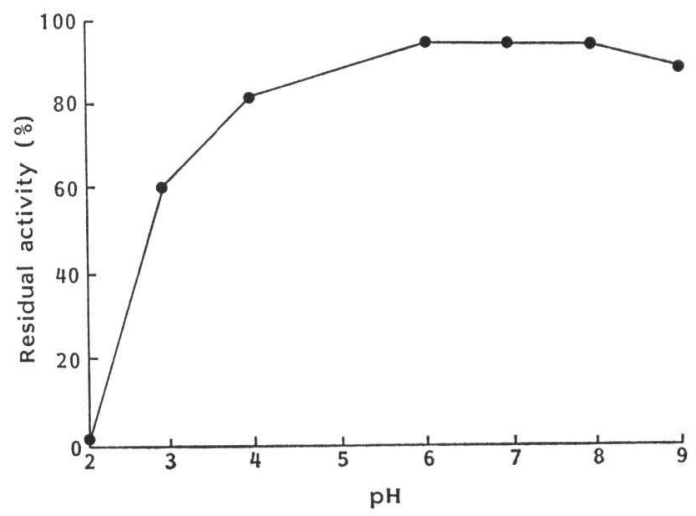

Table 2. Antibacterial spectrum of AN-3.

\begin{tabular}{cr}
\hline \multicolumn{1}{c}{ Microorganisms } & $\begin{array}{c}\text { MIC } \\
(\mu \mathrm{g} / \mathrm{ml})\end{array}$ \\
\hline Escherichia coli W3876 & $>100$ \\
" $\quad$ MP2 & 11 \\
UR3 & 11 \\
Bacillus subtilis ATCC 6633 & $>100$ \\
Micrococcus luteus ATCC 9341 & $>100$ \\
Staphylococcus aureus FDA 209P & $>100$ \\
Pseudomonas aeruginosa ATCC 10145 & $>100$ \\
\hline
\end{tabular}

Figs. 4 and 5 show the infrared spectrum and UV absorption spectrum of AN-3, respectively. Both spectra also suggest that $\mathrm{AN}-3$ is a polypeptide. We could not detect any nonprotein chromophoric component in $\mathrm{AN}-3$ by the method employed in detecting one in neocarzinostatin ${ }^{4}$. No shoulder or peak in the absorption spectrum other than the peak at $280 \mathrm{~nm}$ was found in AN-3 (Fig. 5), also suggesting the absence of a chromophore.

Amino acid analysis showed that AN-3 contained various kinds of amino acids, some of which are lacked by other proteinaceous antibiotics (Table 1).

AN-3 was stable at $\mathrm{pH} 4 \sim 9$, and very unstable when exposed to $\mathrm{pH} 2$ (Fig. 6).

Biological Properties

\section{Antibacterial Activity}

The antibacterial activity of AN-3 is summarized in Table 2. AN-3 showed no antibacterial activity against Gram-positive or Gram-negative bacteria, so far as tested. The exception was that AN-3 showed a strong inhibitory effect on MP2, a macromolecule permeable mutant of E. coli W3876. AN-3 showed a similar growth inhibitory effect on its $u v r \mathrm{~A}$ and $r e c \mathrm{~A}$ double mutant, UR3. Therefore, as 
Fig. 7. Inhibitory effect of AN-3 on incorporation of radioactive precursors into macromolecules in $E$. coli MP2.

(A) Cells were incubated at the indicated concentrations of AN-3 for 30 minutes.

(B) Cells were incubated for the indicated times with $20 \mu \mathrm{g} / \mathrm{ml}$ of AN-3. After the incubation and washing of cells, a labeled precursor was added and cultivation was continued. At intervals aliquots of cultures were withdrawn and subjected to measurement of the incorporation of labeled precursors as described in Materials and Methods.

(○), $\left[{ }^{3} \mathrm{H}\right]$ leucine; (뭄), $\left[{ }^{3} \mathrm{H}\right]$ uracil; (ㅇ) $\left[{ }^{3} \mathrm{H}\right]$ thymidine.
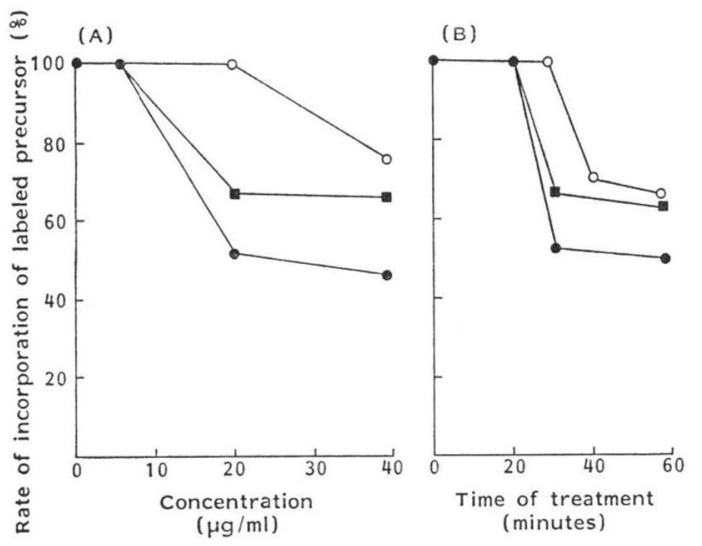

discussed in previous papers, ${ }^{1,2)} \mathrm{AN}-3$ appeared not to possess any significant direct DNA-interacting property.

\section{Mutagenic Activity}

The mutagenic activity of AN-3 was examined with a mutagenicity detecting system in which valine-resistant mutants induced by the drug were quantitatively measured. At a concentration of $1 \sim 100 \mu \mathrm{g} / \mathrm{ml}$, AN-3 did not increase the mutation frequency, although the viable cell number decreased proportionally with increasing concentration of AN-3.

\section{Effect of AN-3 on Synthesis of DNA, RNA} and Protein

The effect of AN-3 on the synthesis of cellular macromolecules in MP2 was examined by determining its influence on the incorporation of radioactive precursors into macromolecules. As indicated in Fig. 7, AN-3 appeared to inhibit the synthesis of DNA and RNA under the same treatment conditions under which protein synthesis was not significantly altered. Since, AN-3

does not seem to interact directly with DNA for the reasons mentioned above, the site of its action must have been somewhere other than DNA itself. No further study on this point has been done.

\section{Antitumor Activity of AN-3}

AN-3 was examined for its antitumor activity in vitro and in vivo. Neocarzinostatin and bleomycin were also tested as reference antitumor agents. Every peptide antibiotic tested was inhibitory toward the in vitro growth of L1210. When their antitumor activity was examined by using an in vivo assay system with L1210 cells in mouse, only neocarzinostatin was active. AN-3 and bleomycin were found to be effective inhibitors of in vivo development of Lewis lung carcinomas (Table 3).

Table 3. Antitumor activity of AN-3.

\begin{tabular}{|c|c|c|c|c|c|}
\hline \multirow{3}{*}{ Antibiotics } & \multirow{3}{*}{ 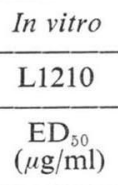 } & \multicolumn{4}{|c|}{ In vivo } \\
\hline & & \multicolumn{2}{|c|}{ L1210 leukemia } & \multicolumn{2}{|c|}{ Lewis lung carcinoma } \\
\hline & & $\begin{array}{c}\text { Dose } \\
(\mathrm{mg} / \mathrm{kg})\end{array}$ & $\underset{(\%)^{*}}{\text { ILS }}$ & $\begin{array}{c}\text { Dose } \\
(\mathrm{mg} / \mathrm{kg})\end{array}$ & $\begin{array}{l}\text { Reduction of } \\
\text { size }(\%)\end{array}$ \\
\hline AN-3 & 5.0 & 25 & —** & $20 \sim 25$ & $57 \sim 71$ \\
\hline Neocarzinostatin & 0.10 & 0.25 & $155 \sim 174$ & 0.25 & - \\
\hline Bleomycin & 0.85 & 5 & - & $5 \sim 10$ & $52 \sim 68$ \\
\hline
\end{tabular}

* Increase in life span, ILS of control is $100 \%$.

** Not affected. 


\section{Discussion}

AN-3 was isolated and purified from the culture fluid of S. albulus by using our newly developed procedure.

AN-3 appeared to be a novel protein antibiotic for the following reasons. It was different from plurallin ${ }^{5)}$, iyomycin complex ${ }^{(6)}$, carzinocidin ${ }^{7)}$, melanomycin ${ }^{3)}, \mathrm{A}-280^{9)}$, peptimycin ${ }^{10)}$ and lymphomy$\mathrm{cin}^{11)}$, because purified samples of all these macromolecular antibiotics were reportedly chromogenic as compared to the white powder of AN-3. Neocarzinostatin ${ }^{12)}$, macromomycin ${ }^{13)}$ and actinoxanthin ${ }^{14)}$ were isolated as antibiotics of an acidic polypeptide nature, but AN-3 is a basic polypeptide.

As for basic peptide antibiotics, AN-3 was different from phenomycin ${ }^{15)}$ and sporamycin ${ }^{18)}$ because AN-3 contained some amino acids which are lacking in other antibiotics. Phenomycin was deficient in phenylalanine, and sporamycin in histidine, arginine, methionine and proline. AN-3 was completely insoluble in organic solvents and so differed from actinocarcin ${ }^{17}$ ) which is soluble in 1-butanol - pyridine water $(1: 1: 2)$. Two other basic peptide antibiotics, A $216^{9)}$ and enomycin ${ }^{18)}$ show different $\mathrm{pH}$ stabilities from $\mathrm{AN}-3$. These antibiotics are not very unstable at $\mathrm{pH} 1 \sim 2$, wheras $\mathrm{AN}-3$ is very unstable.

$\mathrm{AN}-3$ has an unique biological property among the macromolecular peptide antibiotics. For the reasons mentioned earlier, AN-3 does not appear to interact directly with DNA to any significant extent. The non-mutagenic property of AN-3 supports this, since many DNA-interacting chemicals are mutagenic. Yet, it showed a strong growth inhibitory effect on L1210 cells in vitro and Lewis lung carcinoma tissue in vivo.

Since we could not detect any chromophore in AN-3, the characteristics of AN-3 may in fact reflect the activity of the polypeptide itself.

\section{Acknowledgments}

The authors are indebted to Drs. Y. Hirose, K. TAKINAmI and H. Enel of Ajinomoto Co. for their encouragement.

\section{References}

1) Udaka, S. \& S. Miyashiro: A new test system for screening macromolecular antitumor antibiotics and its application to culture fluids of actinomycetes. J. Antibiotics 35: 1312 1318, 1982

2) Miyashiro, S. \& S. Udaka: Screening and some properties of new macromolecular peptide antibiotics. J. Antibiotics 35: 1319 1325, 1982

3) Miyashiro, S. \& S. Udaka: Optimum culture conditions for production of macromolecular peptide antibiotics: AN-1, AN-3 and AN-7. Submitted for publication.

4) Katten, L. S.; M. A. NAPier \& I. H. GoldberG: Rule of chromophore and apo-protein in neocarzinostatin action. Proc. Natl. Acad. Sci. USA 77: 1970 1974, 1980

5) Ogawara, H.; K. Maeda, K. Nitta, Y. Okami, T. Takeuchi \& H. Umezawa: An antibiotic, plurallin, consisting of a pluramycin-like prosthetic group and a glycoprotein. J. Antibiotics, Ser. A 19: 1 9, 1966

6) Nomura, S.; H. Yamamoto, A. Matsumae \& T. Hata: Iyomycin, a new antitumor antibiotics from Streptomyces. I. Isolation and properties of iyomycin complex. J. Antibiotics, Ser. A 17: 104 111, 1964

7) Harada, Y.; T. Nara \& F. OKamoto: Studies on carzinocidin, an antitumor substance, produced by Streptomyces sp. I. On extraction, chemical and biological properties of carzinocidin. J. Antibiotics, Ser. A 9: 6 8, 1956

8) Sugawara, R.; A. Matsumae \& T. Hata: Melanomycin, a new antitumor substance from Streptomyces. I. J. Antibiotics, Ser. A 10: 133 137, 1957

9) Sekizawa, Y.; S. Inouye \& K. Kagino: On the isolation and antitumor properties of macromolecular substances produced by Streptomyces species. J. Antibiotics, Ser. A 15: 236 241, 1962

10) Murase, M.; T. Hikiji, K. Nitta, Y. Okami, T. Takeuchi \& H. Umezawa: Peptimycin, a product of Streptomyces exhibiting apparent inhibition against Ehrlich carcinoma. J. Antibiotics, Ser. A 14: 113 118, 1961

11) Ishida, N.; F. Suzuki, H. Maeda, K. OzU \& K. KumagaI: Isolation and characterization of lymphomycin. J. Antibiotics 22: 218 227, 1969 
12) Ishida, N.; K. Miyazaki, K. Kumagai \& M. Rikimaru: Neocarzinostatin, an antitumor antibiotic of high molecular weight: Isolation, physicochemical properties and biological activities. J. Antibiotics 18: 68 76,1965

13) Chimura, H.; M. Ishizuka, M. Hamada, S. Hori, K. Kimura, J. Inanaga, T. Takeuchi \& H. Umezawa: A new antibiotic, macromomycin, exhibiting antitumor activity and antimicrobial activity. J. Antibiotics $21: 44 \sim 49,1968$

14) Khokhlov, A. S.; B. Z. Cherches, P. D. Reshetov, G. M. Smirnova, I. B. Sorokina, T. A. Prokoptzeva, T. A. Koloditskaya \& V. V. Smirnov: Physico-chemical and biological studies on actinoxanthin, an antibiotic from Actinomyces globisporus 1131. J. Antibiotics 22: 541 544, 1969

15) Nakamura, S.; T. Yajima, M. Hamada, T. Nishimura, M. Ishizuka, T. Takeuchi, N. Tanaka \& H. UMEZAWA: A new antitumor antibiotic, phenomycin. J. Antibiotics, Ser. A 20: 210 216, 1967

16) Umezawa, H.; K. Komiyama, H. Takeshima, J. Awaya \& S. Ōmura: A new antitumor antibiotic, PO-357. J. Antibiotics 29: 1249 1251, 1974

17) Kinara, T.; S. Takeuchi \& H. Yonehara: Studies on actinocarcin, a new antitumor antibiotic. J. Antibiotics 27: 994 996, 1974

18) Suhara, Y.; M. Ishizuka, Y. Okami, T. Takeuchi \& H. Umezawa: Studies on enomycin, a new antitumor substance. J. Antibiotics, Ser. A 16: 107 108, 1963 